\title{
REKRUTMEN, SELEKSI DAN PENEMPATAN SYARIAH
}

\author{
Nun Tuhfa*
}

\begin{abstract}
The theme of the article is the business concept in Islamic economics. The purpose of writing is: to analyze recruitment, selection and placement based on Islamic law. This article is a study of literature. Islam is the most perfect religion. everything in Islam comes from God. God has revealed Al-Qur'an as a guideline for the Islamic ummah in carrying out every aspect of life. Hadiths are also used as a basis for Muslims. So is the case with the concept of Islamic human resource management. This paper explains how the Islamic Perspective regarding the process of recruitment, selection and placement of human resources. How is the process and implementation of recruitment, selection and placement in the Koran and Hadith which is the main reference for Muslims.
\end{abstract}

Keywords: Recruitment, Selection, Placement

* Dosen Fakultas Ekonomi dan Bisnis Islam INZAH Genggong Kraksaan Probolinggo 


\section{A. PENDAHULUAN}

Sumber daya manusia adalah salah satu aset terpenting dalam organisasi, bahkan menjadi asset paling menetukan tercapainya visi dan misi organisasi. Karena itu penting mencari sumber daya manusia terbaik dari para pelamar yang didapat dari proses rekrutmen, kemudian menjaga dan memeliharanya dengan baik. Fungsi pertama dari manajemen sumber daya manusia adalah perencanaan, rekrutmen dan seleksi. Sumber daya manusia merupakan aset penting yang wajib dijaga (Tubagus, 2015).

Perencanaan sumber daya manusia adalah proses awal yang berusaha memproyeksikan keperluan akan tenaga baru dengan karakteristik yang sesuai dengan visi dan misi serta budaya organisasi. Selanjutnya adalah proses rekrutmen. Rekrutmen merupakan proses megoreksi sumber daya manusia yang sanggup untuk meyempurnakan segala kekurangan dalam orgnisasi. Dalam prosesnya, rekrutmen adalah mengumpulkan seluruh pelamar untuk selanjutnya diseleksi. Seleksi merupakan proses menggali informasi mengenai pelamar kemudian memutuskan siapa yang layak dan tidak untuk menjadi bagian dari oraganisasi. Dari proses seleksi kemudian organisasi mendapatkan sumber daya manusia yang layak menempati posisi tertentu. Proses berikutnya adalah penempatan. Penempatan merupakan proses memposisikan para pelamar yang terpilih sesuai dengan keahliannya.

Dari paparan di atas dapat disimpukan bahwa proses perencanaan dan rekrutmen dalam manajemen sumber daya manusia adalah proses yang panjang dan tidak mudah, serta membutuhkan biaya yang tidak sedikit. Hal ini dilakukan hampir semua organisasi karena dengan tujuan agar sumber daya manusia yang dimilikinya merupakan sumber daya manusia pilihan yang mampu dan kompeten dalam memegang amanah organisasi. Islam sebagai agama yang paling sampurna, telah memberikan tuntunan di dalamnya meliputi seluruh aktivitas manusia, mulai yang berkaitan dengan ibadah wajib maupun ibadah yang sunah, karena pada hakikatnya seluruh aktivitas manusia adalah ibadah. Tentu dengan niat yang benar. Allah telah menurunkan Alquran sebagai aturan untuk umat manusia, serta Allah telah mengutus Nabi Muhammad SAW untuk menjelaskan dan memantapkan isi Alquran dengan hadistNya.

Begitu juga dengan manajemen sumber daya manusia. Alqur'an dan hadist telah menjelaskan bagaimana sumber daya manusia ini agar 
mendapat keberhasilan atau falah. Sumber daya manusia lebih dikenal dengan sumber daya insani.

Dalam Alqur'an dan Hadist terdapat pedoman bagaimana manjemen sumber daya manusia dalam pandangan Islam atau yang lebih dikenal dengan manjemen sumber daya insani. Manajemen sumber daya insani adalah (Ibrahim, 2006) seputar penentuan aktivitas karyawan, seleksi calon karyawan, pelatihan dan pengembangan karyawan serta semua aktivitas lain terkait awal masuk karyawan hingga masa pensiun. Defenisi ini dapat diartikan bahwa proses awal untuk menjalankan organisasi adalah rekrutmen dan seleksi sumber daya manusia. Rekrutmen dan seleksi menjadi kunci keberhasilan organisasi dalam menjalankan kegiatan untuk mencapai tujuan-tujuan organisasi.

Suatu sistem yang sesuai dengan syariat dijamin kebehasilannya, yang dalam istilahnya dikenal dengan falah. Falah dapat diartikan sebagai buah dari usaha seseorang yang sesuai dengan syariat islam. Rekrutmen dan seleksi yang mengikuti syariat tentu akan mendapatkan hasil yang maksimal, karena syariat mensyaratkan bagi calon pekerja agar dipilih yang memiliki keahlian serta pengalaman seperti yang telah Allah firmankan yang artinya:

"Karena sesunggubnya orang yang paling baik yang kamu ambil untuk bekerja (pada kita) adalah orang yang kuatlagi dapat dipercaya" (AlQashas [28]:26)

Rasulullah SAW bersabda:

"Iika urusan diserabkan bukan pada ablinya, maka tunggulab kebancuran itu" (Bukhari-6015).

Dari ayat dan hadist di atas jelas bahwa dalam proses rekrumen dibutuhkan seleksi yang jujur dan adil sehingga sesuai dengan tuntunan syariat, yang pada ahirnya akan melahirkan sumber daya manusia yang professional serta bertanggung jawab. Tentu dengan demikian organisasi akan mendapatkan manfaat yang maksimal. Dari sini penulis mencoba menkaji lebih detail tentang proses rekrutmen, seleksi dan penempatan sumber daya manusia yang sesuai syariat. 


\section{B. KAJIAN PUSTAKA}

\section{Rekrutmen}

Rekrutmen adalah hal yang pertama dilakukan manajemen sumber daya manusia. Rekrutmen adalah lanjutan setelah adanya proses analisis jabatan dan perencanaan sumber daya manusia. Adanya rekrutmen karena kebutuhan organisasi akan sumber daya manusia untuk menempati posisi yang kosong dalam sebuah organisasi. Hal ini tentu setelah dilakukannya analisis jabatan dan perencanaan. Beberapa pendapat para tokoh mengenai rekrutmen;

a) Rekrutmen (Hasibuan 2008) adalah proses penarikan seleksi, penempatan, orietasi daninduksi untuk mendapatkan karyawan yang efektif dan efiseien memantu tercapainya tujuan perusahaan.

b) Rekrutmen (Ardana, dkk, 2012) adalah suatu proses mencari tenaga kerja atau karyawan dan mendorong serta memberikan suatu harapan dari mereka untuk melamar pekerjaan pada perusahaan.

c) Rekrutmen (Kasmir, 2012) adalah kegiatan untuk menarik sejumlah pelamar agar melamar ke lembaga

d) Rekrutmen (Mondy, 2008) adalah proses pencarian atau mengundang tenaga kerja yang mempunyai kemampuan sesuai dengan rencana dan kebutuhan organisasi diwaktu tertentu untuk melamar kerja.

Dari beberapa pendapat di atas dapat disimpulkan bahwa rekrutmen merupakan proses awal untuk memenuhi kebutuhan akan sember daya manusia dalam organisasi. Rekrutmen diawali dengan proses pencarian pelamar baik dari internal maupun eksternal organisasi. Para pelamar mengajukan lamara entah dengan cara tradisioanal ataupun dengan cara digital, kemudian organisasi menyeleksi sesuai kebutuhan. Proses rekrutmen akan meghasikan surat atau file lamaran kerja yang siap untuk diseleksi di tahap berikutnya.

Proses rekrutmen akan memberikan kesempatan bagi organsasi untuk memilih sumber daya manusia yang paling baik diantara para pelamar yang ada. Tentu harus sesuai dengan tuntunan syariat serta sesuai dengan kebutuhan organisasi. Dengan demikian proses rekrutmen sangat menentukan tercapainya visi misi oranisasi, karena sumber daya manusialah yang akan menjalani sistem yang telah dibangun dalam sebuah oganisasi. 


\section{Sumber Rekrutmen}

Terdapat dua sumber dalam proses rekrutmen, yaitu:

A. Rekrutmen Internal

Rekrutmen internal adalah mengisi posisi yang lowong dengan calon dari dalam, prosesini memiliki banyak keuntungan. Pertama, sebenarnya tidak ada penggantian untuk mengetahui kekuatan dan kelemahan seorang calon. Karenanya seringkali lebih aman untuk mempromosikan karyawan dari dalam. Calon dari dalam dianggap lebih berkomitmen kepada organisasi, serta membutuhkan lebih sedikit orientasi dan pelatihan dari pada calon dari luar (Dessler,2003:111).

Sumber-sumber internal meliputi karyawan yang ada sekarang yang dapat dicalonkan untuk dipromosikan, dipindahtugaskan atau diretasi tugasnya, serta mantan karyawan yang bisa dikaryakan dipanggil kembali (Schuer \& Jakson,1996:232)

Untuk melakukan rekrutmen internal kegiatan yang populer dan banyak digunakan diantaranya adalah (Nawawi,2000:175) :

a) Rencana suksesi

b) Penawaran terbuka untuk satu jabatan (job posting)

c) Perbantuan pekerja

d) Kelompok pekerja sementara

e) Promosi dan pemindahan

B. Rekrutmen Eksternal

Perusahaan tidak selalu bisa mendapatkan semua karyawan yang mereka butuhkan dari staf yang ada sekarang, dan terkadang mereka juga tidak ada keinginan mengabil calon dari dalam. Rekrutmen ekstenal adalah proses mendapatkan tenaga kerja dari pasar tenaga kerja di luar organisasi.

Sumber rekrutmen eksternal meliputi individu-individu yang saat ini bukan merupakan anggota organisasi. Manfaat terbesar rekrutmen eksternal adalah bahwa jumlah pelamar yang lebih banyak dapat direkrut. Hal ini tentunya mengarah kepada kelompok pelamar yang lebih besar dan kompeten daripada yang normalnya dapat direkrut secara internal. Pelamar dari luar tentu membawa ide, teknik kerja, metode produksi, atau pelatihan yang baru ke dalam organisasi yang nantinya akan menghasilkan wawasan baru kedalam profitabilitas. 
Setiap organisasi atau perusahaan secara periodik memerlukan tenaga kerja dari pasar tenaga kerja diluar organisasi atau perusahaan. Pasar tenaga kerja merupakan sumber tenaga kerja yang sangat berpariasi. Beberapa bentuknya adalah (Nawawi,2000:178)
a. Hubungan denga universitas
b. Eksekutif mencari perusahaan
c. Agen tenaga kerja
d. Rekrutmen dengan advertensi

\section{Seleksi}

Seleksi adalah kegiatan dalam manajemen sumber daya manusia yang dilaksanakan setelah proses rekrutmen selesai dilaksanakan (tubagus, 2015).

Proses awal seleksi (Schuler \& Jackson 2006):

a) Menetapkan kriteria-kriteria yang diinginkan.

b) Memilih berbagai prediktor (ragam informasi yang diperlukan untuk melakukan seleksi) dan teknik-teknik penilaian.

c) Menentukan waktu yang tepat untuk mengukur setiap prediktor.

d) Mengolah informasi yang terkumpul dan mengambil keputusan seleksi.

Tes-tes yang dilakukan oleh organisasi dalam metode seleksi ini adalah (tubagus, 2015):
a) Tes kognitif
b) Tes psikomotorik
c) Tes interpersonal
d) Wawancara
e) Tes kepribadian

\section{Penempatan}

Penempatan adalah menempatkan posisi seseeorang ke posisi pekerjaan yang tepat, seberapa baik seorang pegawai cocok dengan pekerjaanya akan mempengaruhi jumlah dan kualitas pekerjaan (Mathis \& Jackson, 2006:262). Jenis-jenis penempatan menurut Effendi dalam Munadin (2011). 
a. Promosi

Promosi adalah menaikan jabatan seseorang kejabatan lain yang memiliki tanggung jawab lebih besar, gaji lebih besar dan pada level organisasi lebih besar. Sudah barang tentu promosi dilakukan dengan baik dalam rangka menjawab tantangan manajemen yang dihadapi yaitu pengisian jabatan, pengembangan pegawai, peningkatan kepuasan kerja, dan peningkatan motivasi kerja

b. Transfer

Transfer adalah pemindahan pegawai dari satu jabatan ke jabatan lain yang memiliki tanggung jawab yang sama, gaji yang sama, dan level organisasi yang sama.

c. Demosi

Demosi adalah pemindahan pegawai dari jabatan lain yang memiliki tanggung jawab lebih rendah, gaji lebih rendah, dan level organisasi yang lebih rendah.

d. Pemutusan Hubungan Kerja

Pemutusan hubungan kerja adalah keadaan yang mungkin terjadi dalam suatu pekerjaan, yang dapat disebabkan oleh berbagai macam alasan seperti disiplin, ekonomi, bisnis, dan alasan-alasan pribadi.

\section{PEMBAHASAN}

\section{Rekrutmen Dalam Perspektif Islam}

Islam sangat memperhatikan betapa pentingnya proses rekrutmen ini sesuai dengan tuntunan syariat. Karena seperti yang kita pahami bahwa pross rekrutmen akan mempengaruhi kinerja yang pada gilirannya akan berpengaruh pada tercapainya tujuan oganisasi. Islam sangat menyerukan agar proses rekrutmen berjalan dengan jujur dan adil agar tujuan rekrutmen untuk mendapatkan sumber daya manusia yang handal dapat terpenuhi. Hal ini jelas dalam Al qur`an surat Al-Qashash [28] ayat 26 yang artinya:

"Dan salah seorang dari kedua (perempuan) itu berkata: "Wahai Ayabku! Jadikanlab ia sebagai orang yang bekerja (pada kita), Sesunggubnya orang yang paling baik yang engkau ambil sebagai pekerja (pada kita) ialah orang yang kuat dan dapat dipercaya"

Ayat ini menjelaskan bahwa sumber daya manusia yang layak 
dijadikan bagian dari organisasi adalah mereka yang kuat dan dapat dipercaya. Meskipun pada zaman nabi sumber daya manusia yang dimaksud adalah unrtuk angkatan perang, tentu kekuatan disini sangat penting mengingat para sumber daya mansianya adalah untuk berperang. Sedangkan pada saat ini kuat dapat diartikan sebagai orang yang sehat jasmani dan rohani. Sebagai karyawan sangat dibutuhkan fisik yang sehat dan jasmani yang kuat, sehingga mampu melaksanakan tugas yang dibebakan padany. Hampir seluruh organisasi mengharuskan bagi pelamar kerja untuk melampirkan surat bukti sehat jasmani dan rohani dari dokter spesialis.

Dalam ayat tersebut juga dikatakan bahwa sumber daya manusia yang direkrut adalah memiliki sifat dapat dipercaya, artinya sumber daya manusia yang direkrut memiliki sifat jujur dan mampu menjalankan amanah dengan baik. Jujur adalah modal utama seseorang. Jika seluruh karyawan organisasi memiliki sifat jujur maka bisa dipastikan organisasi itu akan kondusif, tidak perlu diawasi karena sifat jujur mereka karena perasaan diawasi oleh Allah SWT.

Pendagan lain mengenai tafsiran ayat diatas (Ibrahim, 2006), amanah adalah bagian dari faktor penting untuk menentukan kepatutan dan kelayakan seorang calon karyawan, karyawan harus melaksanakan segala kewajiban sesuai dengan ketentuan Allah dan takut terhadap aturan Nya, melaksankan tugas yang dijalankan dengan sebaik mungkin sesuai prosedurnya tidak diwarnai dengan nepotisme, tindak kezoliman, penipuan, intimidasi, atau kecenderungan terhadap golongan tertentu. Pentingnya merekrut karyawan yang amanah juga ditegaskan Rosulullah SAW dalam hadis yang diriwayatkan oleh Imam Bukhari dari Abu Hurairah. Rosulullah bersabda:

"Ketika menyia-nyiakan amanah, maka tunggulab kehancuran. Dikatakan, hai Rosulullah, apa yang membuatnya sia-sia? Rosulullab bersabda: "ketika suatu perkara diserabkan kepada orang yang bukan ablinya, maka tunggulab kehancuranya".

Hadist ini menekankan pentingnya merekrut karyawan yang amanah, yang tidak menyia-nyiakan kepercayaan yang telah diamanatkan kepada karyawan tersebut, dengan kata lain karyawan harus bisa menjalankan tugas sesuai dengan apa yang dibebankan kepadanya, dan tidak menghianati 
kepercayaan yang diberikan kepadanya. Apabila karyawan tidak amanah maka berdampak buruk pada kinerja dan pada gilirannya akan berdampak pada tidak tercapainya tujuan organisasi. Selain itu hadist diatas juga menganjurkan untuk merekrut sumber daya manusia sesuai bidang ilmu atau keahlian dengan posisi yang dibutuhkan dalam organisasi. Tujuan nya adalah untuk memposisikan orang ditempat yang sesuai dengan keahlian nya, baik ilmu maupun keterampilan yang dimiliki. Dengan demikian setiap karyawan mengerti dan paham apa yang menjadi tugasnya, apa yang harus dikerjakan dan apa yang menjadi tanggung jawabnya. Sebagai implementasi dari hadist diatas pada proses rekrutmen organisasi harusmencantumkan syarat bidang keilmuan atau pendidikan pelamar yang disesuaikan dengan posisi yang akan direkrut. Atau mensyaratkanadanya pengalaman kerja pada bidang yang sama. Ada banyak Ayat dan Hadist yang bisa kita jadikan pedoman dalam proses rekrutmen. Rekrutmen sangat menentukan keberhasilan proses perencanaan sumber daya manusia, karena proses rekrutmen adalah langkah awal sebelum dilanjutkan pada proses seleksi dan penempatan karyawan. Karena dalam Islam proses atau pekerjaan yang diawali dengan baik akan menghasilkan kebaikan dan sebaliknya, pekerjaan yang diawali dengan keburukan akan mengakibatkan kegagalan dalam pencapaian hasil yang baik.

\section{Seleksi Menurut Syariat Islam}

Seleksi merupakan proses lanjutan dari rekrutmen. Surat lamaran yang merupakan hasil rekrutmen yang sudah siap untuk diseleksi. Seleksi merupakan proses menentukan sember daya manusia yang layak diterima dalam oganisasi. Seleksi haruslah sesuai dengan kebutuhan yang diperlukan (tubagus, 2015) hal ini sejalan dengan sabda Rosulullah SAW yang artiya:

"Barang siapa yang mempekerjakan orang karena ada unsur nepotisme, padahal disana terdapat orang yanglebib baik dari pada orang tersebut, maka ia telah menghianati amanah yang diberikan Allah, Rasul-Nya, dan kaum muslimin."

Dari hadist ini dapat disimpulkan bahwa proses seleksi harus benar-benar berasaskan kejujuran dan penuh amanah. Tidak melihat 
siapa dan dari mana tapi bagaimana sumber daya manusia itu memilki kemampuan, keahlian serta pengalaman dalam bidangnya. Prinsipnya seleksi adalah mencari sumber daya manusia yang memiliki kemampuan, keahlian, pengalaman, sehingga seleksi yang menghabiskan banyak biaya dapat menemukan sumber daya manusia yang benar-benar layak bagi organisasi. Dalam hadist itu juga tidak dibenarkan dalam proses seleksi terdapat unsur nepotisme, yang disebutkan menghianati amanah Allah dan RasulNya beserta umat muslim. Sehingga perbuatan semacam itu adalah perbuatan dholim karena menempatkan sebuah posisi bukan pada ahlinya yang akan berujung dosa. Terdapat berbagai cara atau metode dalam seleksi. Seperti wawancara, tes potensi akademik, tes kesehatan. Dari serangkaian proses seleksi yang sangat panjang otomatis akan tersaring siapa yang terbaik dari para pelamar. Landasan hukum proses seleksi dalam syariat islam juga ter;lihat jelas dari ungkapan kholifah Ali bin Abi Thalib R.A yang artinya :

"Jika engkau ingin mengangkat pegawai, maka piliblah secara selektif. Janganlab engkau mengangkat pegawai karena ada unsur kecintaan dan kemuliaan (nepotisme), karena hal ini akan menciptakan golongan durbaka dan kbianat. Piliblab pegawai karena pengalaman dan kompetensi yang dimiliki, tingkat ketakwaannya dan keturunan orang shaleh, serta orang yang memiliki akblak mulia, argumen yang shabih, tidak mengejar kemuliaan (pangkat) dan memiliki pandangan yang luas atas suatu pekerjaan".

Dari maqol di atas maka jelas bahwa tidak dibenarkan merekut sember daya manusia berdasarkan kedekatan seperti kerabat, sahabat yang mereka tidak memiliki kompetensi yang dibutuhkan organisasi. Selain hal ini jelas tidak dibenarkan juga akan merugikan organisasi. Dengan merekrut sumber daya manusia yang tidak kompeten maka jelas akan berdampak pada kinerja yang pada gilirannya akan mempengaruhi tidak tercapainya visi dan misi organisasi. Untuk menghindari berbagai kemungkinan yang tdak diinginkan maka organisasi harus menerapkan prinsip sesuai syariat dalam proses rekrutmen maupun seleksi. Dari maqol diatas juga dapat ditarik kesimpulan beberapa criteria individu yag layak dijadikan standart dalam proses rekrutmen atau pun seleksi yaitu: 
a) Kompeten dan Berpengalaman

Kompeten atau kompetensi maksudnya adalah sumber daya manusia yang meiliki kemampuan yang mempuni dalam bidangnya, serta memahami etika serta mengapikasikannya sesuai ajaran syariat. Begitu juga dengan pengalaman, sumber daya manusia yang berpengalaman akan berbeda dalam melaksanakan tugasnya. Karena mereka telah mengerti degan baik bagaimana menyelesaikan tugas dengan efektif dan efisien.

b) Keturunan Orang Sholeh dan Bertakwa

Sumber daya manusia yang dilahirkan dari orang sholeh yang memiliki pemahaman agama yang baik tentu akan memiliki pemahaman agama yang baik juga. Maka kecil kemungkinan baginya untuk tidak memenuhi segala amanah yang dibebankan padanya. Ketaqwaan akan membuat seseorang enggan untuk melakukan sesuatu yang merugikan orang lain, karena dia takut akan Siksa Allah di akhirat kelak. Dengan demikian dalam dunia kerja sumber daya manusia yang bertaqwa akan berperilaku sesuai tuntutan oganisasi begitu juga organisasi.

c) Berakhlak Mulia

Sumber daya manusia dengan akhlak mulia akan sangat membantu sebuah organisasi. Akhlak mulia adalah akhlak yang sesuai dengan tuntutan syariat yang dibawa oleh makhluk paling mulia yaitu Nabi Muhammad SAW. Melaksanakan amanah tanpa ada unsur paksaan atau ada tekanan dari atasan karena pada prinsipnya orang sholeh adalah sholeh dari hatinya, jadi segala perbuatannya adalah murni dari hatinya. Tidak berhenti disitu, sumber daya manusia yang berakhlak mulia dapat menjalin hubungan dengan baik karena dia akan berbuat baik kepada semua orang, sehingga terbentuk team work dengan disertai lingkungan yang kondusif.

d) Berargument Yang Shahih

Banyak orang pintar dan pandai berargument tapi tidak semua argumentnya dapat diterima. Argument yang baik akan sangat membantu tercapainya visi dan misi organisasi. Argument yan sahih adalah argument yang didalamnya terdapat unsur kebenaran yang sesuai dengan syariat, sehingga dapat diterima dan bermanfaat bagi organisasi. 
e) Tidak Gila Kemuliaan

Sumber daya manusia yang ikhlas bekerja bagi organisasi tidak akan mengharapkan imbalan apalagi jabatan. Jabatan apapun tidak pantas ditempati mereka yang sangat menginginkannya apalagi sangat mendambakannya. Hal ini karena jabatan adalah amanah dan orang beriman sangat hati-hati dengan amanah. Rasulullah SAW bersabda yang artinya:"Demi Allah, wahai pamanku, aku tidak akan menyerabkan persoalan ini, kepada siapapun yang memintanya atau sangat menginginkannya"

f) Berpandangan luas

Sumber daya manusia yang berpandangan luas akan mampu memecahkan masalah dengan bijaksana, karena mereka memecahkan masalah dengan berbagai sudut pandang, sehingga dalam memecahkan masalah dalam organisasi mereka sangat bijaksana dan pada akhirnya masalah akan terselesaikan dengan baik.

\section{Penempatan Dalam Perspektif Islam}

Penempatan adalah proses memposisikan tempat atau jabatan bagi para sumber daya manusia yang telah lolos proses seleksi. Penempatan haruslah sesuai dengan prinsip yang diajarkan oleh Rasulullah SAW dalam sabdaNya:

"Sesunggubnya Allah sangat mencintai orang yang jikamelakukan suatu pekerjaan dilakukan secara itqon (Professional)" (HR. Tabrani)

Dalam hadist ini jelas bahwa profesionalitas jadi prinsip utama alam proses penempatan. Ketepatan dalam proses ini sangat menentukan. Salah dalam penempatan akan berakibat buruk bagi organisasi. Apabila bidang pekerjaan tertentu dikerjaan orang yang salah maka bisa hampir dipastikan hasilnya tidak kan maksimal. Dari paparan ini jelas bahwa profsionalitas sangat dibutuhkan. Dalam islam professional ditandai dengan tiga hal (Yusanto, 2002)yakni kafaah (keahlian), himmatul'amal (etos kerja yang tinggi), amanah (terpercaya).

a. Kafaab (Keahlian)

Merupakan hal yang berhubungan dengan keahlian dan kecakapan.

Ketetapan Islam dalam mengangkat dan menempatkan karyawan 
haruslah sesuai antara keahlian dan kecakapan dengan tugas atau amanah yang embannya. Oleh karena itu penempatan haruslah dilakukan dengan tepat.

b. Himmatul'amal (etos kerja yang tinggi)

Karyawan yang memiliki etos kerja tinggi melakukan tugas dengan penuh keiklasan, sungguh-sungguh dengan semangat tinggi, mencapai sasaran kerja yang telah ditetapkan tanpa ada sedikitpun kesalahan. Selain itu karyawan yang memiliki etos kerja tinggi memandang pekerjaan sebagai ladang ibadah tidak hanya sebatas aktualisasi diri dan mencari penghargaan atau penghasilan semata.

c. Amanah (terpercaya)

Sumber daya manusia yang amanah adalah mereka yang menjalankan tugasnya dengan jujur, penuh tanggung jawab, sesuai prosedur, tidak menyalahi aturan.

Penempatan karyawan harus dilakukan dengan baik dan tepat, karena penempatan sangat memiliki peran penting untuk pelaksaan tugas kedepannya. Berbagai penelitian menyatakan bahwa penempatan mempengaruhi beberapa variabel diantaranya:

a) Motivasi

Penempatan juga merupakan salah satu faktor yang mempengaruhi motivasi kerja karyawan, meskipun banyak faktor lain yang memberikan pengaruh terhadap motivasi, penempatan tidak bisa diabaikan dalam meningkatkan motivasi karyawan. Jika penempatan terlaksana dengan tepat, maka karyawan juga memiliki motivasi ting gi untuk bekerja dan sebaliknya jika penempatan tidak terlaksana dengan baik, karyawan tidak akan termotivasi untuk menyelesaikan tugas.

b) Kinerja

Dari hasil penelitian menyatakan bahwa penempatan yang tepat akan mengakibatkan terwjudnya kinerja dengan baik dan sebaliknya penempatan yang kurang baik akan menghasilkan kinerja yang tidak memuaskan.

c) Kepuasan kerja

Hubungan kepuasan kerja sejalan dengan ketepatan dalam proses penemptan kerja artinya jika penempatan karyawan tepat maka 
tingkat kepuasan kerja karyawan juga mengalami peningkatan dan sebaliknya jika penempatan kurang tepat maka tingkat kepuasan kerja juga mengalami peningkatan.

d) Prestasi kerja

Penempatan juga memepengaruhi prestasi kerja karyawan, karyawan akan memiliki prestasi kerja bagus jika karyawan tersebut ditempatkan pada posisi yang tepat sesuai dengan keilmuan dan keahlian yang dimiliki. Selain menempatkan sumber daya manusia sesuai dengan bidang keahlian atau ilmu yang dimilikinya organisasi juga harus mempertimbangkan kesediaan dan kesanggupan sumber daya manusia tersebut dalam melaksanakan tanggung jawab yang dipikulnya, karena Rasulullah SAW sendiri berprinsip tidak membebankan pekerjaan pada seseorang melewati batas kesanggupannya. Salah satu tujuan proses seleksi yaitu mempertanyakan kesanggupan karyawan untuk melaksanakan tugas yang diberikan, dalam proses seleksi karyawan diwawancarai dengan salah satu pertanyaan apakah dia sanggup dan bersedia di tempatkan pada suatu posisi, sehingga pada saat penempatan tidak terjadi kesalahan dalam penempatan posisi. Al-Quran juga menceritakan bahwa nabi Yusuf AS pernah diamanatkan untuk menjadi bendaharawan negera. Sebelum diangkat, raja menanyakan kesangupannya dalam memikul amanah dan nabi Yusuf AS pun menjawab dengan menyanggupi amanah yang diberikan raja dengan menguatkan bahwa ia memiliki kemampuan di bidang tersebut. Berikut arti surat yusuf ayat 54-55:

"Bawalah dia (Yusuf) kepadaku, agar aku memilih dia (sebagai orang yang dekat) kepadaku." Ketika dia (raja) telah bercakap-cakap dengan dia, dia (raja) berkata, "Sesunggubnya kamu (mulai) hari ini menjadi seorang yang berkedudukan tinggi di lingkungan kami dan dipercayai." Dia (Yusuf) berkata, "Jadikanlah aku bendaharawan negeri (Mesir); karena sesunggubnya aku adalab orang yang pandai menjaga dan berpengetahuan.” (Q. S. Yusuf: 54-55)

Dari ayat diatas dapat kita lihat bahwa nabi Yusuf AS menyanggupi permintaan raja karena nabi Yusuf AS merasa pantas dan layak menerima jabatan tersebut. Nabi Yusuf memahami apa yang menjadi tugas dan tanggung jawab jika diangkat menjadi bendaharawan negeri. Dengan adanya pengetahuan dan ilmu yang sesuai dengan 
jabatan atau posisi yang diamanatkan, setiap tugas yang diberikan akan terlaksana dengan baik dan sempurna. Konsep Islam sejalan dengan konsep manajemen sumber daya manusia, "Right Man on the Right Place". Penempatan harus dilakukan dengan tepat, sesuai dengan kemampuan, keahlian kesanggupan. Penempatan yang salah dan keliru mengakibatkan terhalangnya pencapaian kinerja karyawan. Selain itu penempatan yang salah juga mengakibatkan karir karyawan yang statis. Dan banyak dampak buruk akibat salah penempatan. Dari penjelasan dapat kita tarik kesimpulan bahwa penempatan memiliki peran penting dalam pelaksanaan kerja, dan Islam juga telah mengatur bagaimana pelaksanaan penempatan. Oleh karena itu penempatan harus dilakukan sesuai dengan teori dan konsep Islam untuk agar tujuan dan capaian kinerja organisasi dapat tercapai dengan baik.

\section{Kesimpulan}

Agama islam adalah agama yang paling dirahmati oleh Allah SWT. Agama islam adalah agama paling lengkap dalam memberI tuntunan bagi pemeluknya. Dalam urusan ibadah wajib, sunnah bahkan seluruh aktifitas manusia diatur dengan rinci. Termasuk bagaimana dalam proses rekrutmen, seleksi dan penempatan dalam manajemen sumber daya manusia. Terdapat banyak ayat dan hadist yang menerangkan tentang bagaimana rekrutmen seleksi dan penempatan yang baik. Pada hakekatnya prinsip rekrutmen, seleksi dan penempatan islam sama dengan prinsip rekrutmen seleksi dan penempatan pada umumnya. Proses rekrutmen, seleksi dan penempatan pada prinsipnya harus dilakukan dengan baik dan tepat agar tersedianya karyawan yang pantas dan layak untuk menempati posisi dan jabatan tertentu dalam organisasi. dan layak untuk menempati posisi atau jabatan tertentu dalam organisasi. 


\section{Daftar Pustaka}

Ardanab, I Komang, dkk. 2012. Manajemen Sumber Daya Manusia. Yogyakarta: Graha Ilmu.

Kasmir. Manajemen Perbankan. Jakarta: Rajawali Pers. 2012.

Achmad, Tubagus, 2015. Konsep-konsep Dasar Manajemen Personalia Masa Kini (Bandung:Refika Aditama)

Hasibuan, Melayu. 2008. Manajemen Dasar, Pengertian, Dan Masalah. jakarta: PT Bumi Aksara.

Ibrahim, Abu Sinn, Ahmad. 2006. Manajemen Syariat. Jakarta: Raja Grafindo.

Mondy, Wayne R. 2008. Human Resource Management. 10th ed. Upper Saddle River, N.J.: Pearson Prentice Hall. (Dessler,2003:111).

Muhammad Ismail Yusanto dan Muhamad Karebet Widjajakusuma, Menggagas Bisnis Islam, Gema Insani, Jakarta, 2002.

Nawawi, H, HADASFI, 2000 Manajemen Sumber Daya Manusia, Cetakan Ketiga. Yogyakarta:Gama Press

Schuler, R. S. \& Jackson, S. E. 2006. Human Resource Management, International Perspective. Thomson South-Western: Mason. 